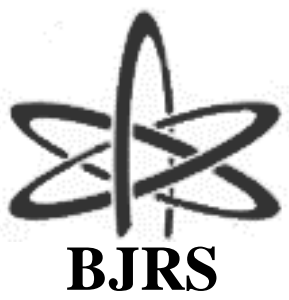

BRAZILIAN JOURNAL

$\mathrm{OF}$

RADIATION SCIENCES

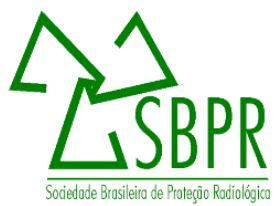

07-03 (2019) 01-14

\title{
Mammography in Brazil: regulatory actions of acceptable levels for glandular dose
}

\author{
J. C. S. Feital a; J. U. Delgado ${ }^{\text {a; }}$ R. T. LOPES ${ }^{\text {b }}$ \\ ${ }^{a}$ Institute of Radiation Protection and Dosimetry, IRD. Av. Salvador Allende s/n. CEP 22780-160 \\ Rio de Janeiro, Brazil. \\ ${ }^{b}$ Nuclear Engineering Program /COPPE-Tecnology Center - University City: CEP 21949-900, \\ Rio de Janeiro, Brazil. \\ E-mail address: jfeital@ird.gov.br
}

\begin{abstract}
The breast is one of the major organs in terms of in terms of biological effects according to the International Commission on Radiological Protection (ICRP), and therefore one of the highest weighting factors for the estimation of risk of cancer induction due to practice of Mammography. In Brazil the Radiodiagnostic Technician Regulation Medical and Dental (National Code 453, 1998) does not contemplate acceptable levels to Mean Glandular Dose (MGD), nor about the actions of the regulatory body regarding exposures in different thicknesses of compression and breast glandularity in the implementation of mammographic screening programs. The objective of this paper is to present and compare with other studies, the results of measurements of MGD in a breast phantom. The adequate traceability was showed in measurements of these quantities, and 56 results in 3 different mammographers to the MGD were compared with the acceptable levels of IAEA, obtaining a $97 \%$ index. In most of these comparisons and within each effective depth measurements of the MGD, achieved $75 \%$ accuracy in relation to acceptable content. A statistical test was applied in four samples involving the two sets target-used filter. From these results, are suggested regulatory actions to meet acceptable levels of MGD.
\end{abstract}

Keywords: Mammography, Glandular dose, Traceability, National code of practice. 


\section{INTRODUCTION}

In any radiographic procedure is very important that the dose of radiation is as low as reasonably possible, keeping the radiographic image quality. This is particularly important in $\mathrm{x}$-ray sensitive organs as breast and in the implementation of programmers in which the exposed population is asymptomatic, as a screening mammographic program for the early detection of breast cancer. In any radiographic procedure is very important that the dose of radiation is as low as reasonably possible, keeping the radiographic image quality. On the other hand, is already widely acceptable and recognized that the glandular tissue of the breast is the most sensitive [1,2] and the quantity Mean Glandular Dose (MGD) becomes the most suitable to predict the risk of induced cancer by ionizing radiation [2]. The Radiodiagnostic Technical Regulation in Brazil [3] is not report about the acceptable levels for the quantity MGD. On the other hand, the International Commission on Radiation Protection (ICRP) [4] reports that in terms of reference levels for the doses in mammography, should be used at least one of the three quantities: air incident kerma $\left(\mathrm{K}_{\mathrm{a}, \mathrm{i}}\right)$, entrance surface air kerma $\left(\mathrm{K}_{\mathrm{a}, \mathrm{e}}\right)$ or Glandular Dose, according to the practices carried out in each situation and objectives required. So after almost two decades, it is observed that such national technical regulation is out of date, because due to the emergence of news quantities and more realistic breast phantoms that can replace with metrological reliability the polymethyl metacrylate phantoms $[5,6]$. Therefore, the aim of this work is to present the results of studies with the necessary comparisons and discussions, enabling the inclusion by the National Regulator, acceptable levels for the MGD. Besides, regulatory actions are reinforced for inclusion of acceptable levels for MGD, enabling the radiation safety necessary for screening mammographic program for early detection of breast cancer, as well as the MGD monitoring for quality control purposes [7], once these procedures are already underway in Brazil. 


\section{MATERIALS AND METHODS}

The following materials were used for experimental measurements:

1 - Three computed mammographers: (I) manufactured by Siemens, model mammomat 1000; (II) manufactured by Philips, model VMI Grafhomamo and (III) manufactured by General Electric, model DMR Senograph;

2 - Breast phantom developed in IRD (BTE), with material with the same characteristics as human tissue [5];

3 - Thermoluminescence dosimeters (TLD) / LiF 100, traced in the laboratory standard manufactured by Harshaw Co [8];

4 - Reader of TLD, model 5500, manufactured by Harshaw Co;

5 - Oven to the heat treatment of dosimeters, manufactured by PTW Co;

6 - Ionization chamber manufactured by Radcal Co, model 10 x 15-6 m and traced in the laboratory standard [8];

7 - Aluminum plates for measurements of half value layer (HVL) in $\mathrm{mm} \mathrm{Al}$, manufactured by "Nuclear Associates" Co.

Figure 1 shows the sequential scheme of the methodology as describe above.

Figure 1: Sequential scheme of the methodology.

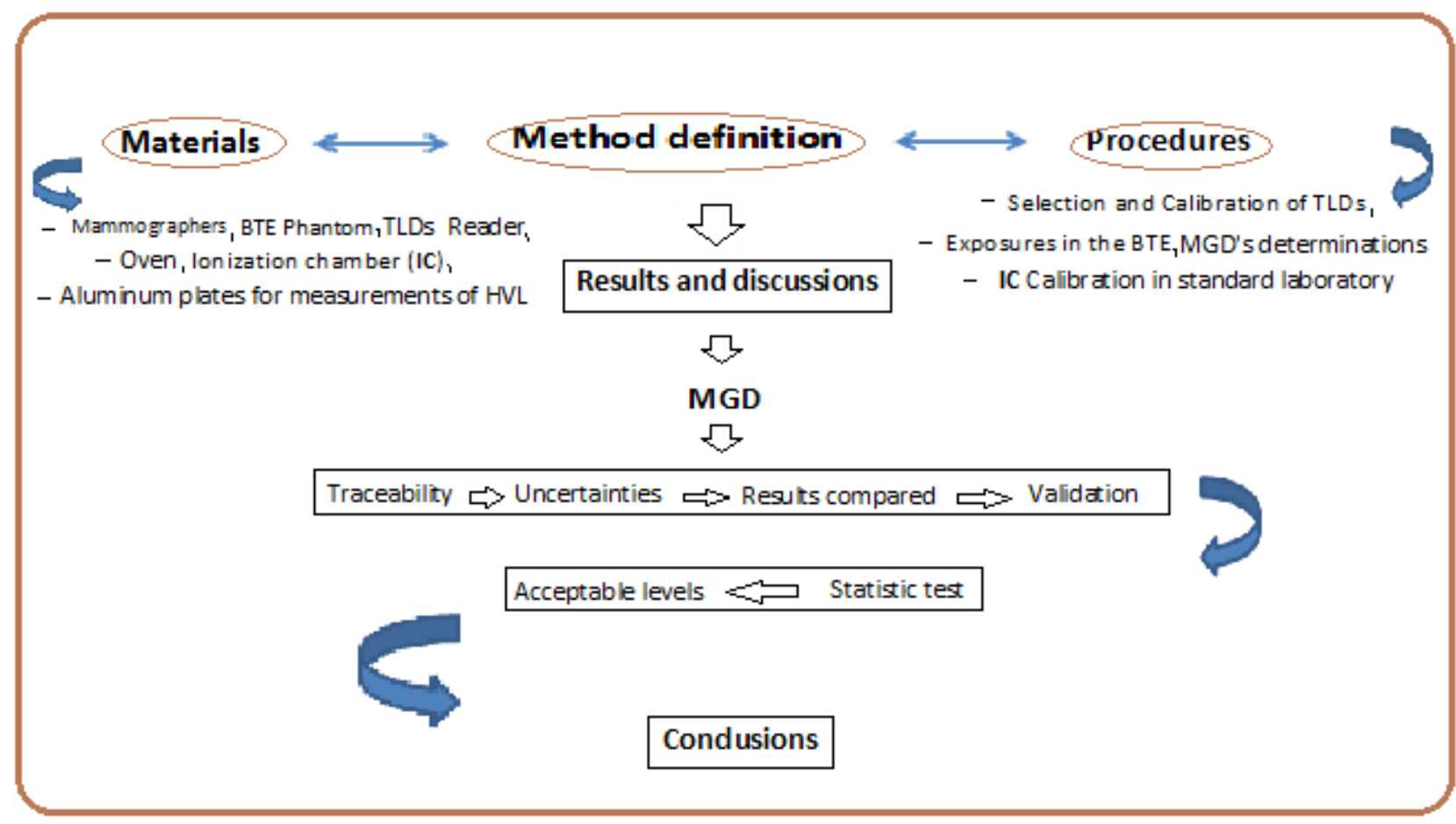


The methods used for selection and calibration of TLDs, measurements and calculations for obtaining results of the MGD in different thicknesses of compression and depths based on the anthropomorphic mamma phantom, as well as the determination of the experimental value of the $\mathrm{K}_{\mathrm{a}, \mathrm{i}}$ which followed the procedures reported in literature $[6,9,10]$. The experimental MGD were calculated according to the average value obtaining to the readings of the 3 TLD`s inserted in the slices of the BTE and obtained the respective standard deviation. These values were multiplied by the suitable correction factors to each depth as listed in Table 1, which components of uncertainty will be considered in the final budget [10].

In the calculation of semi-empirical MGD was used the expression [11]:

$$
M G D=K . g . c . s
$$

where $\boldsymbol{K}$ is the incident air-kerma at the upper surface on the breast PMMA phantom; $\boldsymbol{g}$ is the coefficient that converts air-kerma into MGD for having a 50\% glandular composition; $c$ is the conversion factor which takes into account the glandularity of the breast; and $s$ is the factor that corrects for the target / filter combinations. Each value to the MGD in the equation 1 is obtained to a compression thickness $(\boldsymbol{t})$, in $\mathrm{mm}$. The incident air-kerma quantity determined in BTE, $K$, was obtained by multiplying the average value of three arbitrary readings to the each external dosimeter put at the top of the phantom, already deducted the scattered radiation multiplied by your calibration factor.

\section{Components of the uncertainties in the experimental measurements and mathematical calcu- lation results for MGD}

Type-A uncertainties [6]: represented by the values of standard deviations in three determinations of quantity MGD and product of the current (mA) by the exposure time (s) - mAs.

Type-B uncertainties: for the ionization chamber, account is taken of the expanded uncertainty value of the calibration certificated [8]. The calibration factors of the TLDs, the half-value layer (HVL) and reproducibility for the voltage and correction factors $(g, c, s)$ to obtain the calculated MGD are taken from the literature $[6,11$ and 12$]$.

\section{Estatistical test.}

For the statistical testing, it was used the equation 2 [13]: 


$$
Z=\frac{\left|x_{i}-\bar{x}\right|}{S}
$$

where

$x_{i}$ is the further away from the average value of the sample;

$\bar{x}$ is the sample average, and

$S$ is the standard deviation.

This statistic has as hypotheses:

$\mathrm{H}_{0}: \mathrm{x}_{\mathbf{i}}$ is a observation of extreme value; and $\mathrm{H}_{1}$ : $\mathrm{x}_{\mathbf{i}}$ is not an observation of extreme value. Accepting or rejecting the hypothesis $\mathrm{H}_{0}$ or $\mathrm{H}_{1}$, for a significance level of $0.05 \%$ and if $\mathrm{Z}>\mathrm{Z}$ tab ou $\mathrm{Z}<\mathrm{Z}$ $\mathrm{tab}$, in which $\mathrm{Z}$ tab is a critical value based on the $\mathrm{Z}$ distribution and is tabled.

\section{RESULTS AND DISCUSSION}

In the tables 1 and 2 are presented the main components of uncertainty to obtain each value for MGD (experimental and calculated) within the thicknesses of compression studied. From the value of the calibration certified to TLD's, HVL, $\mathrm{kVp}$ and $\mathrm{mAs}$, table 1, combining with the uncertainties for experimental and calculated MGD in different irradiation conditions (table 2) it was possible to obtain the uncertainties for each final MGD. It was used with traceability and validation required. 
Table 1: Components of uncertainty for the determination of experimental MGD [6].

Thickness compressed (cm)

\begin{tabular}{|c|c|c|c|c|c|c|c|c|}
\hline & 3.0 & 3.5 & 4.0 & 4.5 & 5.0 & 5.5 & 6.0 & \\
\hline \multicolumn{8}{|c|}{ Type-A (\%) } & Type-B (\%) \\
\hline MGD $\mathrm{a}_{1}$ & 15.60 & 2.87 & 13.94 & 3.30 & 2.60 & 0.69 & 1.90 & - \\
\hline MGD $\mathrm{a}_{2}$ & 1.98 & 3.26 & 1.95 & 1.44 & 1.39 & 0.68 & 5.17 & - \\
\hline $\mathrm{MGD}_{3}$ & 10.01 & 2.99 & 6.63 & 1.98 & 3.55 & 1.10 & 2.04 & - \\
\hline $\mathrm{MGD} \mathrm{a}_{4}$ & 2.83 & 3.80 & 0.93 & 3.23 & 1.40 & 1.32 & 1.36 & - \\
\hline $\mathrm{mAs} \mathrm{b}_{1}$ & 0.28 & 0.25 & 0.23 & 1.94 & 0.14 & 0.30 & 0.14 & - \\
\hline $\mathrm{mAs} \mathrm{b}_{2}$ & 1.83 & 0.22 & 0.33 & 0.58 & 0.36 & 0.53 & 0.30 & - \\
\hline $\mathrm{mAs} \mathrm{b}_{3}$ & 0.33 & 0.11 & 0.09 & 0.11 & - & 0.38 & 0.05 & - \\
\hline $\mathrm{mAs} \mathrm{b}_{4}$ & 0.00 & 0.00 & 0.12 & 0.09 & 0.38 & 0.09 & 0.28 & - \\
\hline $\mathrm{U}^{\mathrm{c}}$ & - & - & - & - & - & - & - & 1.3 \\
\hline $\operatorname{TLD}^{\mathrm{d}}$ & - & - & - & - & - & - & - & 7.5 \\
\hline $\mathrm{HVL}^{\mathrm{e}}$ & - & - & - & - & - & - & - & 10.0 \\
\hline$k V p^{f}$ & - & - & - & - & - & - & - & 1.99 \\
\hline
\end{tabular}

$\mathrm{a}_{1}, \mathrm{a}_{2} \mathrm{e} \mathrm{b}_{1}, \mathrm{~b}_{2}$ (equipment I) ; $28 \mathrm{kV} ;$ Mo-Mo and Mo-Rh; HVL $=0.38 \mathrm{~mm}$ and $0.41 \mathrm{~mm}$ in Al.

$\mathrm{a}_{3}, \mathrm{a}_{4} \mathrm{e} \mathrm{b}_{3}$, $\mathrm{b}_{4}$ (equipment II and III); $28 \mathrm{kV}$ and Mo-Mo e Mo-Rh; HVL $=0.35 \mathrm{~mm}$ and $0.40 \mathrm{~mm}$ in Al.

c - Expanded Uncertainty [8].

d - Standard deviation [10].

e - Uncertainty to Mo-Mo and Mo-Rh [14, 15].

f - Reproducibility [13]. 
Table 2: Uncertainties for calculated MGD in different irradiation conditions [6].

\begin{tabular}{|c|c|c|c|c|c|c|c|c|}
\hline \multicolumn{9}{|c|}{ Thickness compressed $(\mathrm{cm})$} \\
\hline & 3.0 & 3.5 & 4.0 & 4.5 & 5.0 & 5.5 & 6.0 & \\
\hline \multicolumn{8}{|c|}{ Type-A (\%) } & Type-B (\%) \\
\hline $\mathrm{k}_{\mathrm{a}, \mathrm{i}} \mathrm{a}^{1}$ & 0.53 & 4.10 & 0.72 & 3.60 & 2.73 & 0.41 & 0.34 & - \\
\hline $\mathrm{k}_{\mathrm{a}, \mathrm{i}} \mathrm{a}^{2}$ & 1.89 & 0.97 & 4.00 & 2.06 & 3.24 & 1.88 & 0.40 & - \\
\hline $\mathrm{k}_{\mathrm{a}, \mathrm{i}}{ }^{3}$ & 4.17 & 2.26 & 5.13 & 3.83 & 3.09 & 3.85 & 2.55 & - \\
\hline $\mathrm{k}_{\mathrm{a}, \mathrm{i}} \mathrm{a}$ & 3.48 & 2.06 & 0.30 & 5.18 & 2.16 & 3.39 & 1.06 & - \\
\hline Factor $\mathrm{c}^{\mathrm{b}}$ & - & - & - & - & - & - & & 3.00 \\
\hline Target- fil & & & & & & & & Mo-Mo/Mo-Rh \\
\hline Factor $g^{c}$ & - & - & - & - & - & & & $4.20 / 5.00$ \\
\hline Factor $\mathrm{s}^{\mathrm{d}}$ & - & - & - & - & - & & & $3.10 / 2.20$ \\
\hline
\end{tabular}

$\mathrm{a}_{1}, \mathrm{a}_{2}$ (equipment I) ; $28 \mathrm{kV}$; Mo-Mo; Mo-Rh; HVL $=0.38 \mathrm{~mm}$ and $0.41 \mathrm{~mm}$ in Al.

$\mathrm{a}_{3}$, a 4 (equipment II and III); $28 \mathrm{kV}$; Mo-Mo; Mo-Rh; HVL $=0.35 \mathrm{~mm}$ and $0.40 \mathrm{~mm}$ in $\mathrm{Al}$.

b, c, d [9].

From the results of uncertainties type A (tables 1 and 2), mainly to experimental measurements for MGD, it was observed that the highest values were associated with the target-set filter (Mo-Mo). This is according with the study of SEKIMOTO et al. [16] that report that the doses in mammography are influenced by the set target-filter, which leads to the need for further research to this basic parameter between the measurements of MGD on each mammography unit used from different manufacturers. 
Table 3: Results of the final MGD with uncertainties and accuracy values.

\begin{tabular}{|c|c|c|c|c|c|c|}
\hline \multicolumn{7}{|c|}{$\begin{array}{c}\text { Mammographer I / Mo-Mo } \\
\text { o.38 mm Al }\end{array}$} \\
\hline $\begin{array}{c}\text { Thickness } \\
\text { compressed } \\
(\mathrm{cm})\end{array}$ & $\begin{array}{l}\text { Depth } \\
\text { in the } \\
\text { phantom } \\
(\mathbf{c m})\end{array}$ & $\begin{array}{l}\text { Calc. MGD }{ }^{a} \\
\quad(\mathbf{m G y})\end{array}$ & $\mathbf{U}^{b}$ & $\begin{array}{c}\text { Exp. MGD } \\
(\mathbf{m G y})\end{array}$ & $\mathbf{U}$ & $\underset{(\%)}{\operatorname{Accuracy}}{ }^{\mathrm{d}}$ \\
\hline 3.0 & 1.0 & 0.65 & 0.091 & 0.70 & 0.142 & 8.5 \\
\hline 3.5 & 1.0 & 0.89 & 0.130 & 1.04 & 0.136 & $>15$ \\
\hline 4.0 & 1.5 & 1.09 & 0.154 & 1.03 & 0.194 & 6.3 \\
\hline 4.5 & 2.0 & 1.39 & 0.199 & 0.90 & 0.119 & $>15$ \\
\hline 5.0 & 1,5 & 1.70 & 0.244 & 1.92 & 0.249 & 13.0 \\
\hline 5.5 & 1.5 & 2.34 & 0.328 & 2.89 & 0.368 & $>15$ \\
\hline 6.0 & 2.0 & 3.04 & 0.428 & 2.90 & 0.373 & 5.1 \\
\hline \multicolumn{7}{|c|}{$\begin{array}{c}\text { Mammographer I / Mo-Rh } \\
\text { o.41mm Al }\end{array}$} \\
\hline 3.0 & 1.0 & 0.61 & 0.088 & 0.66 & 0.085 & 7.0 \\
\hline 3.5 & 1.5 & 0.69 & 0.097 & 0.61 & 0.083 & 11.0 \\
\hline 4.0 & 1.5 & 0.82 & 0.120 & 0.82 & 0.106 & 0.7 \\
\hline 4.5 & 1.5 & 1.09 & 0.154 & 1.18 & 0.151 & 7.9 \\
\hline 5.0 & 2.0 & 1.30 & 0.188 & 1.08 & 0.138 & $>15$ \\
\hline 5.5 & 2.0 & 1.60 & 0.228 & 1.47 & 0.187 & 7.3 \\
\hline 6.0 & 2.0 & 1.98 & 0.279 & 2.07 & 0.284 & 4.5 \\
\hline \multicolumn{7}{|c|}{$\begin{array}{l}\text { Mammographer II / Mo-Mo } \\
0.35 \text { mm Al }\end{array}$} \\
\hline 3.0 & 1.0 & 1.01 & 0.141 & 0.96 & 0.220 & 5.0 \\
\hline 3.5 & 1.5 & 1.17 & 0.167 & 1.12 & 1.146 & 4.0 \\
\hline 4.0 & 1.5 & 1.36 & 0.204 & 1,40 & 0.201 & 3.7 \\
\hline 4.5 & 1.5 & 1.50 & 0.225 & 1.71 & 0.220 & 14.0 \\
\hline 5.0 & 2.0 & 1.73 & 0.249 & 1.35 & 0.254 & $>15$ \\
\hline 5.5 & 2.0 & 2.10 & 0.307 & 1.82 & 0.233 & 13.0 \\
\hline 6.0 & 2.0 & 2.66 & 0.381 & 2.45 & 0.316 & 8.0 \\
\hline \multicolumn{7}{|c|}{$\begin{array}{l}\text { Mammographer III / Mo-Rh } \\
\text { 0.40 mm Al }\end{array}$} \\
\hline 3.0 & 1.5 & 0.59 & 0.090 & 0.53 & 0.070 & 10.0 \\
\hline 3.5 & 1.5 & 0.76 & 0.108 & 0.79 & 0.105 & 4.0 \\
\hline 4.0 & 1.5 & 0.85 & 0.119 & 1.07 & 0.137 & $>15$ \\
\hline 4.5 & 2.0 & 1.07 & 0.161 & 0.96 & 0.126 & 10.0 \\
\hline 5.0 & 2.0 & 1.34 & 0.191 & 1.43 & 0.183 & 6.7 \\
\hline 5.5 & 2.0 & 1.67 & 0.238 & 1.89 & 0.242 & 13.2 \\
\hline 6.0 & 2.0 & 2.07 & 0.295 & 2.58 & 0.330 & $>15$ \\
\hline
\end{tabular}

a Calculated.

$b$ Expanded uncertainty.

${ }_{c}$ Experimental.

$d$ Acceptable $\leq 15 \%$ [2]. 
In table 3, for seven thickness of compressed breast and three different depths in about $95 \%$ of the values to the MGD determinations for the expanded uncertainty, were reached an index of up to $15 \%$. In this same table, it were proved that in $75 \%$ of the index obtained in the experimental measurements are validated according to the level of acceptable dose recommended for MGD that is up to $15 \%$ [2]. In another study in a large public hospital in the State of Rio de Janeiro [17], where women were studied aged between 49 to 65 years, were found in about $70 \%$ of this sample a compressed breast thickness between 4.0 to $6.0 \mathrm{~cm}$. This range included between the 56 results for MGD showed in table 3.

Tabela 4: MGD values for thickness compressed of $4.5 \mathrm{~cm}$, $28 \mathrm{kV}$ and $50 \%$ of glandularity.

\begin{tabular}{crcc}
\hline Target/filter & \multicolumn{3}{c}{ MGD (mGy) } \\
\hline & Feital, 2017 & Wu, 1994 & Dance, 2000 \\
\hline Mo-Mo & $0.90 \pm 0.12$ & $1.29(30 \%)^{*}$ & $1.47(39 \%)^{*}$ \\
\hline Mo-Rh & $1.18 \pm 0.15$ & $1.04(13 \%)^{*}$ & $1.13(4 \%)^{*}$ \\
\hline \hline
\end{tabular}

*Comparisons (\%) among the studies of Feital, 2017 [6]; Wu, 1994 [18] and Dance, 2000 [9] .

In table 4 are compared results of MGD to different methodologies and were observed that Mo-Rh set presents the best performance in these comparisons, however in the study development in Medical Physics Division of the IRD was presented the values for the uncertainties allowing for a more consistent conclusion about the results of these measurements. In literature it is reported that the dosimetry under these conditions presents difficulties in terms of accuracy [19].

As a resulted, are shown in figures 2 to 5 the values for MGD, compared to acceptable levels of IAEA within the seven studied thickness compressed $[6,7]$. 
Figure 2: Results for Mo-Mo in the mammographer I.

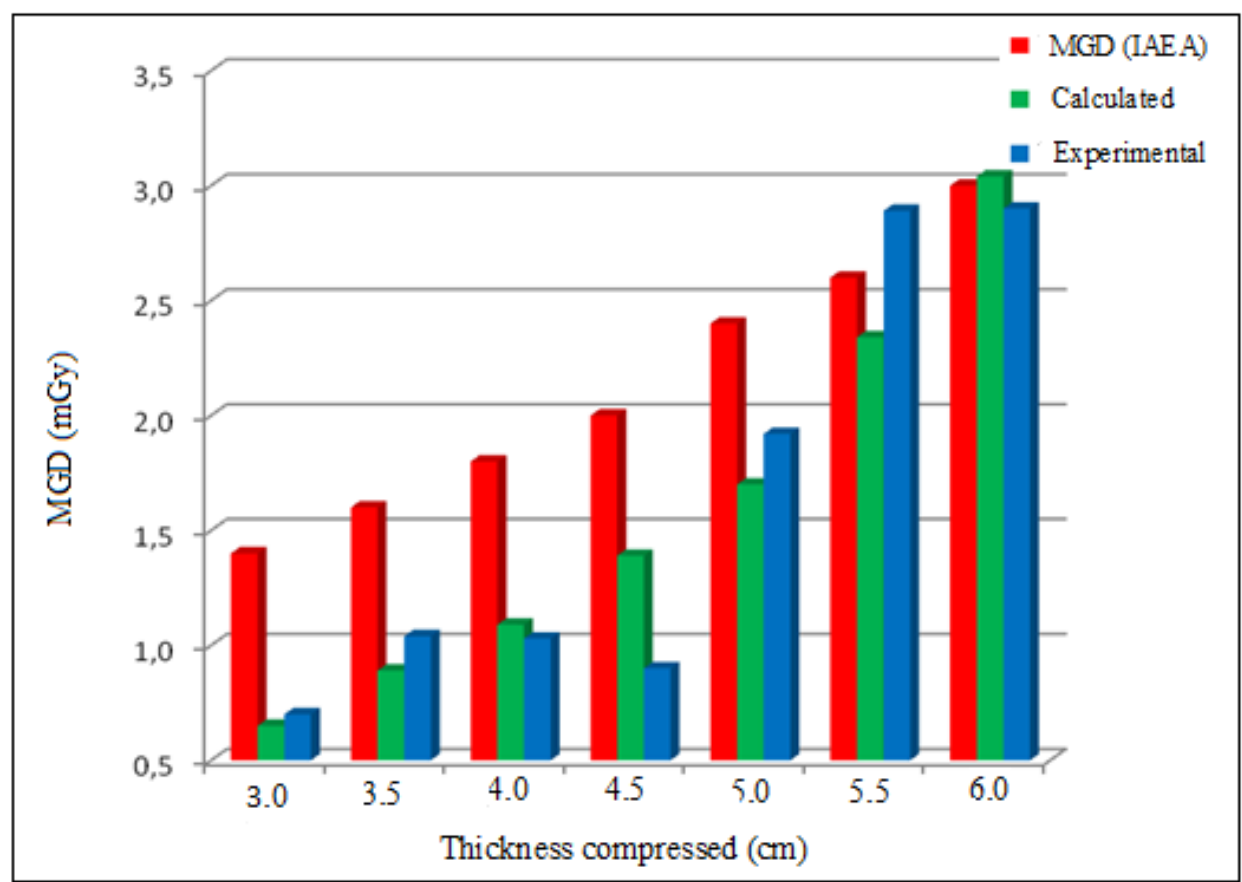

Figure 3: Results for Mo-Rh in the mammographer I.

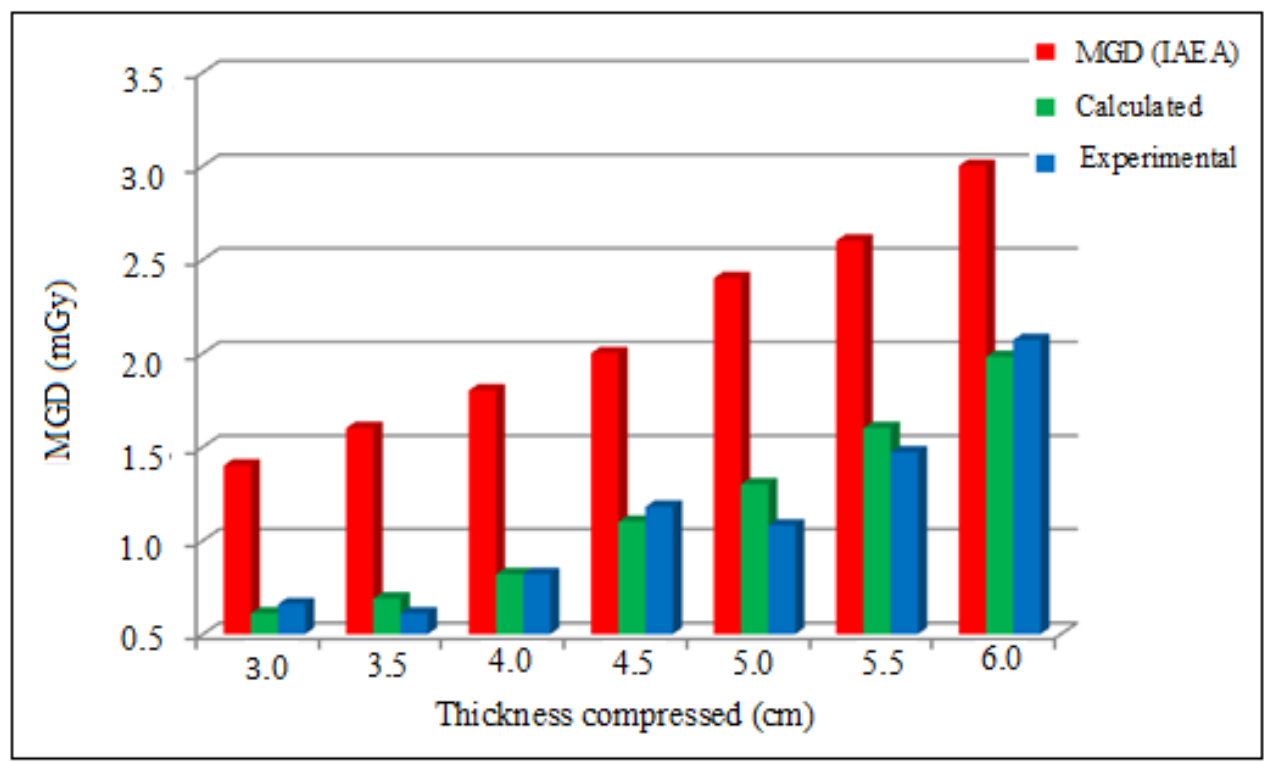


Figure 4: Results for Mo-Mo in the mammographer II.

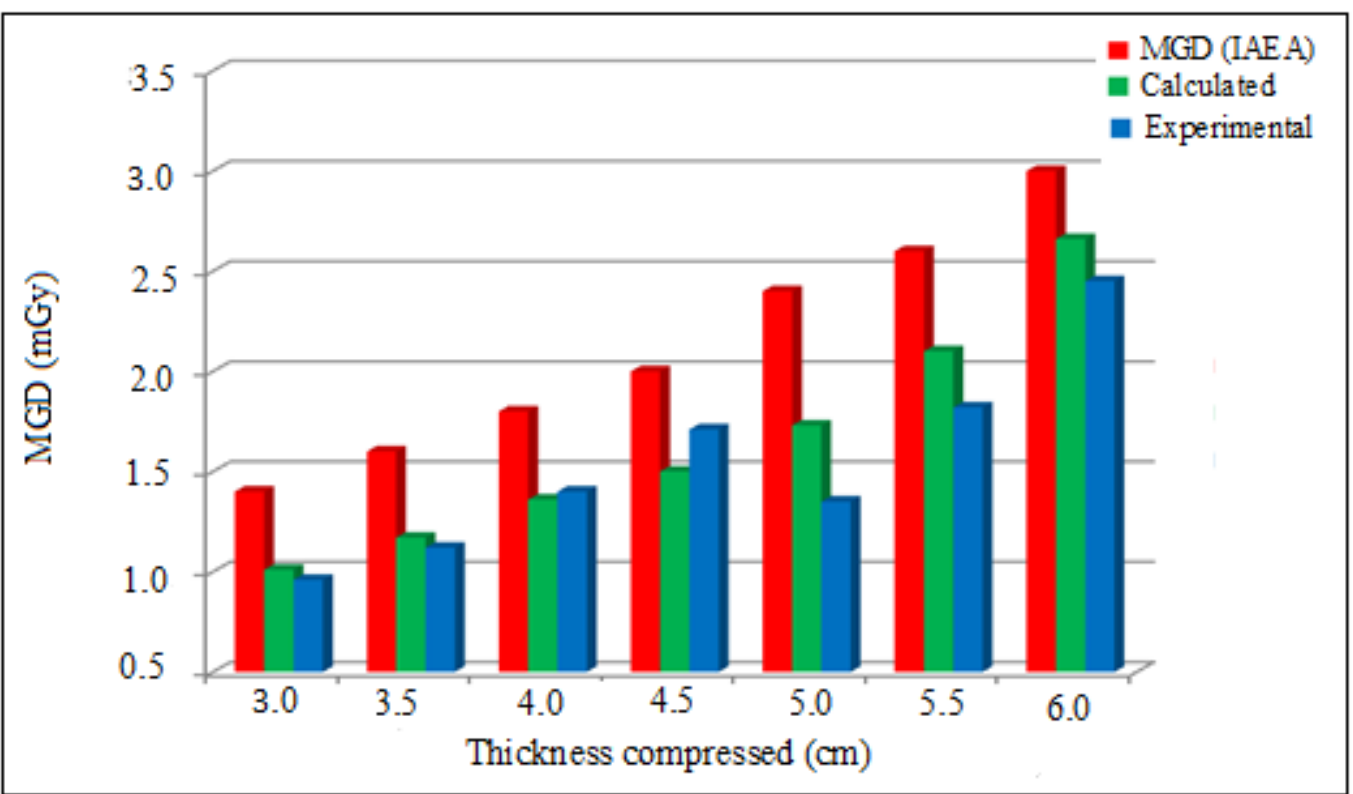

Figure 5: Results for Mo-Mo in the mammographer III.

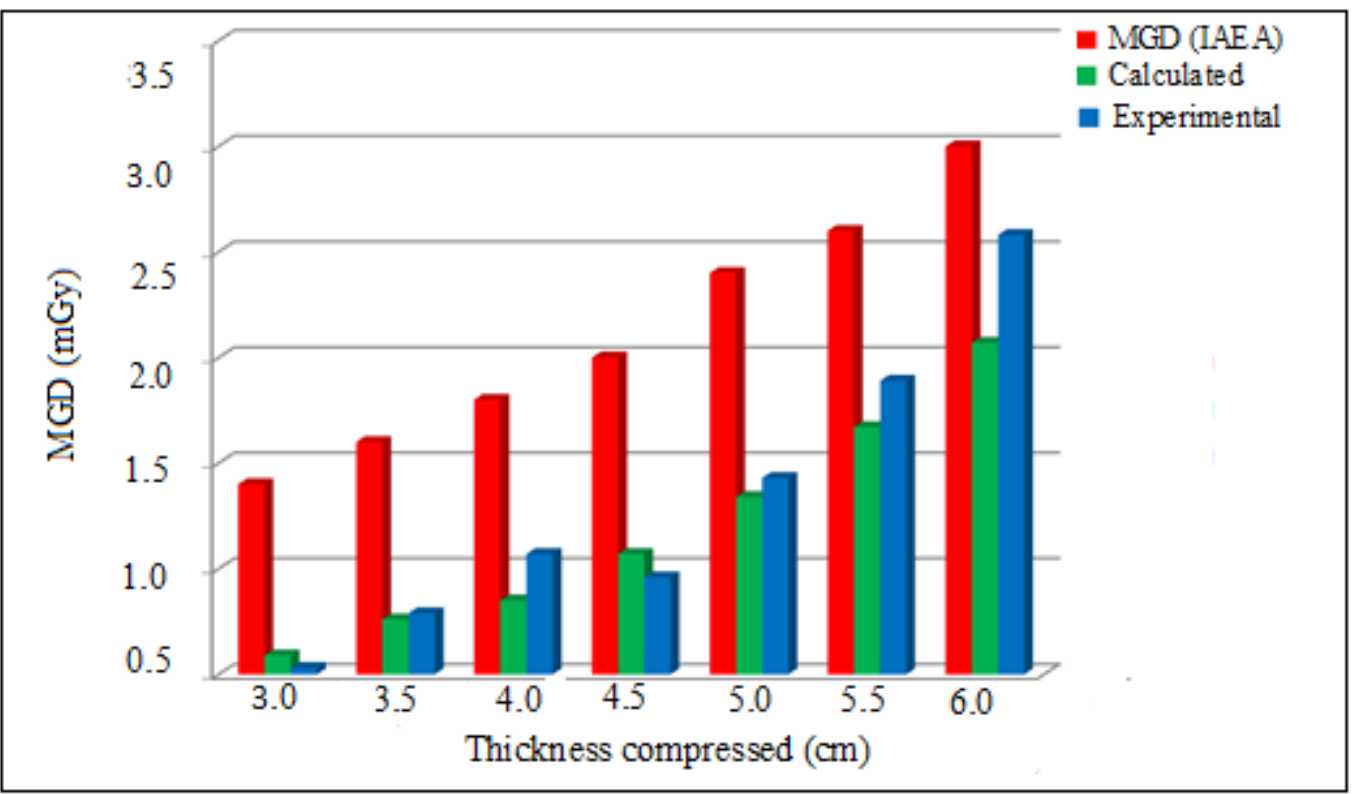

In figures 2 to 5 are shown the 56 values for MGD obtained experimentally and by mathematical calculation where it was found a rate of $97 \%$ for these comparisons in relation to acceptable levels $[6,11]$. 
It was applied statistical test of Grubbs [13] to the results of the determinations of MGD and were used the equation 2 to $n=14$ for each target filter set how showed in the figures 1 to 4 . Four results were obtained for $\mathrm{Z}$ calculated (Zcalc): 1.87; 2.12; 2.23; 2.10; all lesser than $\mathrm{Z}$ tabled (Ztab = 2.37) for a level of significance of 0.05 . According to the hypothesis $\mathrm{H}_{1}$; where $\mathrm{Z}$ calc $<\mathrm{Ztab}$ is not considered an extreme value, it proves the absence of inappropriate values in samples, whether for random variability inherent in the measurements, as well as errors in calculations to obtain data or even data insertion incorrect sample sets.

These determinations was found the maximum value of 3.04 mGy for MGD, encouraging so the realization of screening mammography among the population once every two years without an important potential risk for the patient at this practice of radiodiagnostic [20]. This is justified by the study of HAUGE et al. that adopting the doses of 0.7, 2.5 and $5.7 \mathrm{mGy}$, concluding that the risk to induce cancer with death is minimal due to examinations in mammography screening programs for early detection of breast cancer [21].

\section{CONCLUSION}

The results for MGD obtained as well as their comparisons approve and enable the inclusion of compressed breast thickness range between 4.0 to $6.0 \mathrm{~cm}$ with proper traceability aiming at the adoption of acceptable values for MGD by the National Regulator and its Sanitary Surveillance. The methodology applied and the results obtained in this study reinforce the actions of the Ministry of Health to perform screening mammography in the country.

\section{REFERENCES}

1. BOUZARJOMEHRI, F., MOSTAAR, A., GHASEMI, A., EHRAMPOSH, M. H., KHOSRAVI, H. "The Study of Mean Glandular Dose in Mammography in Yazd and the Factors Affecting It", Iranian Journal of Radiology, v. 4, n. 1, 2006.

2. KLEIN, R., AICHINGER, H., DIEKER, J., JANSEN, J. T. M., JOITE-BARFUe, S., SABEL, M., SCHULZ-WENDLAND, R., ZOETELIEF, J. "Determination of glandular dose with modern 
mammography units for two large groups of patients”, Physics in Medicine and Biology, v. 42, pp. 651-671, 1997.

3. MS - MINISTÉRIO DA SAÚDE. Diretrizes de Proteção Radiológica em Radiodiagnóstico Médico e Odontológico - Portaria nº 453. Diário Oficial da União n. 103, 1998.

4. ICRP - INTERNATIONAL COMMISSION ON RADIOLOGICAL PROTECTION. Diagnostic Reference Levels in Medical Imaging (draft report for consultation). Annals of the ICRP, n. XXI, 2016.

5. AlMEIDA, C.D; COUTINHO, C.M., DANTAS, B.M., PEIXOTO, J.E., KOCH, H.A. "A new mammographic dosimetric phantom", Radiation Protection Dosimetry, v. 151, n. 1, pp. 196-198, 2012.

6. FEITAL, J. C. S., 2017, Desenvolvimento de metodologia para medições de dose glandular média por meio de um simulador de mama. Tese de D.Sc., PEN/COPPE/UFRJ, Rio de Janeiro, RJ, Brasil.

7. INCA - National Cancer Institute. Program of Quality Control in Mammography. Available at:: http://www2.inca.gov.br/wps/wcm/connect/acoes >. Last acessed: Sept 15, 2017.

8. LNMRI - LABORATÓRIO NACIONAL DE METROLOGIA DAS RADIAÇÕES IONIZANTES, Certificado de Calibração, LNMRI/IRD-0105. Rio de Janeiro, Brasil, 2015.

9. DANCE, D.R., SKINNER, C.L., YOUNG, K.C., BECKETT, J.R., KOTRE, C.J. "Additional factors for the estimation of mean glandular breast dose using the UK mammography dosimetry protocol". Physics in Medicine and Biology, v. 45, pp. 3225-3240, 2000.

10. SARDO, L. T. L., ALMEIDA, C. D., COUTINHO C. M. C. Preliminary results of the average glandular dose breast with TLDs and calculated by conversion factors. In: International Nuclear Atlantic Conference, Recife, Brasil, 2013.

11. IAEA - INTERNATIONAL AGENCY OF ENERGY ATOMIC. Quality assurance program for digital mammography, Human Series, v. 17, Viena, 2011.

12. OIEA - ORGANISMO INTERNACIONAL DE ENERGIA ATÓMICA, Control de Calidad en Mamografia, Tec. Doc. 1517, Viena, 2006.

13. PORTAL ACTION. Grubbs Test. Available at: < https: //www.Portalaction.com.br>. Last accessed: may 30, 2015. 


\section{EC - EUROPEAN COMMISSION. European Guidelines for Quality Assurance in Breast} Cancer Screening and Diagnosis”. In: PERRY, N., BROEDERS, M., DE WOLF, C. et al. (eds), 4 ed., Office for Official Publications of the European Communities, Luxembourg, 2006.

15. COUTINHO, C. M., 2009, Avaliação da dose glandular em sistemas de mamografia convencional e digital utilizando um fantoma dosimétrico. Tese de D.Sc., PEN/COPPE/UFRJ, Rio de Janeiro, RJ, Brasil.

16. SEKIMOTO, M., KATOH, Y., KATOH, T. "Calibration coefficients of dosimeters used in mammography for various target/filter combinations", Journal of Applied Clinical Medical Physics, v. 16, n. 6, 2015.

17. ALMEIDA, C.D., 2014, Otimização da dose glandular média na mama e da qualidade da imagem nos sistemas de mamografia digital. Tese de D.Sc. Departamento de Radiologia da Faculdade de Medicina da UFRJ, Rio de Janeiro, RJ, Brasil.

18. WU, X., GINGOLD, E. L., BARNES, G. T., D.M. "Normalized average glandular dose in molybdenum target-rhodium filter and rhodium target-rhodium filter mammography", Radiology, v. 193, pp. 83-89, 1994.

19. ANDY, K. W., ALGHAMDI, A. A. "Development of a Realistic Computational Breast Phantom for Dosimetric Simulations", Nuclear Science and Technology, v. 2, pp. 147-152, 2011.

20. PORTAL BRASIL. Early Detection. Available at: <http://www.inca.gov.br/outubrorosa/detecção-precoce.asp>. Last accessed: 30 mar. 2017.

21. HAUGE, I. H. R., PEDERSEN, K., OLERUD, H. M., HOLE, E. O., HOFVING, S. "The risk of radiation-induced breast cancers due to biennial in women aged 50-69 years in minimal", Acta Radiologica, v. 55, n. 10, pp. 1174-1179, 2014. 